http://dx.doi.org/10.11646/phytotaxa.1.1.5

\title{
A new species of Eugenia (Myrtaceae) from South America
}

\author{
FIORELLA F. MAZINE ${ }^{1,3} \&$ JAIR EUSTÁQUIO QUINTINO DE FARIA ${ }^{2}$ \\ ${ }^{1}$ Universidade Federal de São Carlos, campus Sorocaba, Rod. João Leme dos Santos km110, Sorocaba, SP, Brazil \\ ${ }^{2}$ Programa de Pós-Graduação em Botânica, Departamento de Botânica, Universidade de Brasília, C.P. 4457, Brasília, DF, $70919-$ \\ 970, Brazil \\ ${ }_{3}^{3}$ Author for correspondence: email: fiorella@ufscar.br
}

\begin{abstract}
Eugenia densiracemosa, a new species from central Brazil to French Guiana, is described, illustrated and compared to the related Eugenia egensis, from which it is set apart by the longer inflorescences, longer rachis (1.2-6.0 cm long), with 9-25 pairs of flowers, while in E. egensis the inflorescences are smaller, with rachis $0.1-0.6 \mathrm{~cm}$ long, and a smaller number of flowers (1-4 pairs of flowers in each inflorescence).
\end{abstract}

Key words: Eugenia egensis, Myrteae, French Guiana, Brazil

Eugenia L. (1753: 470) is one of the largest genera in Myrtaceae, with 1043 species (WCSP 2013), with the majority of these occurring in central and South America and relatively few in Africa (van der Merwe et al. 2005). In Brazil, it is the most diverse genus in Myrtaceae and also one of the most species-rich genera of the Brazilian flora, with 370 species, 287 of which are endemic to Brazil (Sobral et al. 2013).

During the studies of Eugenia L., several specimens were found in several herbaria that were incorrectly named or filed as Eugenia sp. Further analysis has shown they are an undescribed species broadly distributed through Brazil and French Guiana.

Eugenia densiracemosa Mazine \& Faria, sp. nov. Type:-BRAZIL. Mato Grosso. Chapada dos Guimarães, Parque Nacional da Chapada dos Guimarães, Véu da Noiva, ao longo do rio Coxipozinho, trilha para a base da cachoeira, 15²4'S 5550'W, 15 Jan 2004, F. F. Mazine et al. 1072 (holotype ESA, isotype K). Figure 1.

Shrub or tree $1-10 \mathrm{~m}$. Branches densely pubescent, rarely sparsely. Leaves $6.6-20 \times 1.8-8.5 \mathrm{~cm}$, obovate, oblong to elliptic or narrow-elliptic, base acute or obtuse, apex acuminate, chartaceous or subcoriaceous, adaxially sparsely to moderately pubescent, abaxially glabrous to moderately pubescent, trichomes simple, midvein sulcate or flat adaxially, puberulent to strigose on both sides, lateral veins prominent, 10-13 pairs, first pair of lateral veins confluent with the marginal vein, marginal vein simple $0.8-3.5 \mathrm{~mm}$ from the margin ; glands salient on the lower surface to flat on the upper one; petioles 4-13 $40.9-2 \mathrm{~mm}$. Inflorescences bracteate shoots bearing 9-25 pairs of flowers, axillary or extra-axillary, sessile to subsessile, rachis 1.2-6.0 $\mathrm{cm}$ long, puberulous to densely pubescent, trichomes usually white, sometimes brown. Flower bud 2-3 mm diam.; bracts persistent, deltoid to lanceolate, pubescent, trichomes pale brown, 0.7-1.6 mm long; pedicel $0.2-1.1 \mathrm{~cm}$ long, densely pubescent; bracteoles deltoids, free, $0.5-1.5 \mathrm{~mm}$ long, apex acute, sparsely to densely pubescent, thicker in the region of the midvein, ciliate, persistent; sepals orbicular, $1-2 \times 1.4-1.9$ $\mathrm{mm}$, apex rounded, glabrous to densely pubescent, ciliate, trichomes whitish; hypanthium subglabrous to very densely pubescent; petals white, orbicular to oblong, 2.3-3.7 $\mathrm{mm}$ long, apex rounded to acute, glands salient; stamina disk puberulous, trichomes whitish to brown, stamens $78-86$, anthers with apical gland; style 5-7 mm 
4756'10"W, 17 Nov 2010, J. B. Pereira \& J. P. Amaral 286 (CEN, UB); Porto Nacional, fazenda Mourão, próximo a Porto Nacional, 7 Dec 1999, Arnaldo et al. 1981 (UB); ibid, ponte sobre o rio Tocantins, 17 Aug 1993, E. Santos et al. 197 (HTO, UB). UNKNOWN LOCALITY: "Brasil central", sertão d'Amaroleité, Sep-Oct 1844, M. A. Weddell 2708 (P); Rio Tocantins, ressaca, 28 Jun 1986, Revilla et al. 4536 (INPA). Unknown locality, Nov 1879, Glaziou 10824 (K); Unknown locality, Nov 1879, Glaziou 10826 (K, P); Unknown locality, Nov 1879, Glaziou 10827 (P). FRENCH GUIANA. Cayenne, Monts Bakra, 30 Sep 1980, Granville 4044 (K); Monts d'Arawa, 53²2'04”'O 0248'54”N, 21 Mar 2006, J.F. Molino \& D. Sabatier 2235 (CAY).

$E$. densiracemosa has sessile inflorescences and hypanthia that can be subglabrous to very densely pubescent. The flowers are generally very densely distributed along the rachis of the inflorescence, with very short floral internodes. It is related to Eugenia egensis DC. (1828: 281), differing as the inflorescences in $E$. densiracemosa are longer, the rachis $1.2-6.0 \mathrm{~cm}$ long with 9-25 pairs of flowers, while in E. egensis the inflorescences are shorter, normally barely developed, with rachises $0.1-0.6 \mathrm{~cm}$ long, and a smaller number of flowers (1-4 pairs of flowers in each inflorescence). Also, the rachis of the inflorescences of $E$. densiracemosa is puberulous to densely pubescent, while that of E. egensis is glabrous or subglabrous. The leaf blades of $E$. densiracemosa are sparsely to moderately pubescent on the upper surface, glabrous to moderately pubescent on the lower surface (versus glabrous leaves in E. egensis) and with prominent glands on the lower surface and flat on the upper one (prominent glands in both surfaces in E. egensis).

\section{Acknowledgements}

Authors would like to thank Claudenir Simões Caires for preparing the illustrations. The second author thanks $\mathrm{CNPq}$ for the Masters fellowship and the Postgraduation Program in Botany of UnB for the financial support in the field work. The first author is grateful to the IAPT and FAPESP for providing funding for field work in Mato Grosso state.

\section{References}

De Candolle, A.P. (1828) Myrtaceae. In Prodromus Systematis Universalis Regni Vegetabilis 3: 207-296.

IUCN Standards and Petitions Subcommittee (2010) Guidelines for Using the IUCN Red List Categories and Criteria. Version 8.1. Prepared by the Standards and Petitions Subcommittee in March 2010.

Available from http://intranet.iucn.org/webfiles/doc/SSC/RedList/RedListGuidelines.pdf

Linnaeus, C. (1753) Species plantarum vol. 1. L. Salvius, Stockholm.

Sobral, M., Proença, C., Souza, M., Mazine, F. \& Lucas, E. (2013) Myrtaceae. In Lista de Espécies da Flora do Brasil. Jardim Botânico do Rio de Janeiro. Available from http://floradobrasil.jbrj.gov.br/2012/FB010338.

van der Merwe, M.M., van Wyk, A.E. \& Botha, A.M. (2005) Molecular phylogenetic analysis of Eugenia L. (Myrtaceae), with emphasis on southern African taxa. Plant Systematics and Evolution 251: 21-34. http://dx.doi.org/10.1007/s00606-004-0160-0

WCSP (2013) World Checklist of Selected Plant Families. Facilitated by the Royal Botanic Gardens, Kew. Published on the Internet; http://apps.kew.org/wcsp/. Accessed 16.July.2013. 